Tropical Journal of Pharmaceutical Research September 2017; 16 (9): 2197-2205

ISSN: 1596-5996 (print); 1596-9827 (electronic)

(C) Pharmacotherapy Group, Faculty of Pharmacy, University of Benin, Benin City, 300001 Nigeria.

All rights reserved.

Available online at http://www.tjpr.org

Original Research Article

http://dx.doi.org/10.4314/tjpr.v16i9.22

\title{
Tetramethyl-0-scutellarin isolated from peels of immature Shiranuhi fruit exhibits anti-inflammatory effects on LPS- induced RAW264.7 cells
}

\author{
Ju Mi Hyun ${ }^{1}$, Yeon Jeong Jo, Jung Eun Kim¹, Hyun Joo An², Young Hun Choi ${ }^{2}$, \\ Chang-Gu Hyun ${ }^{1}$ and Nam Ho Lee ${ }^{1 *}$ \\ ${ }^{1}$ Cosmetic Science Center, Department of Chemistry and Cosmetics, Jeju National University, Jeju 63243, ${ }^{2}$ Citrus Research \\ Institute, National Institute of Horticultural \& Herbal Science, RDA, Seogwipo 63607, Korea \\ ${ }^{*}$ For correspondence: Email: namho@jejunu.ac.kr, Tel: +82 647543548
}

\begin{abstract}
Purpose: To investigate the anti-inflammatory activity of the ethanol extract of the immature fruit of a citrus, Shiranuhi, and to identify the active ingredient.

Methods: The immature Shiranuhi peel was extracted with $80 \%$ ethanol, and the extract was fractionated with solvents ( $n$-hexane, ethyl acetate and $n$-butanol) to afford the corresponding fractions and water residue. Among them, the EtOAc-soluble portion was subjected to medium pressure liquid chromatography (MPLC) over a reversed-phase $\mathrm{SiO}_{2}$ column to give compound 1 . The isolated compound was identified based on the proton and carbon nuclear magnetic resonance (NMR) spectra. The release of nitric oxide, prostaglandin (PG)E2, tumor necrosis factor (TNF)- $\alpha$, interleukin (IL)-1 $\beta$, and IL-6 secreted by mouse macrophages was measured using RAW264.7 cell culture supernatant.

Results: Shiranuhi (Korean name, Hallabong) is an important citrus species cultivated in Jeju Island, Korea. A polymethoxyflavonoid (PMF), tetramethyl-O-scutellarin (1), was isolated from the peels of immature Shiranuhi fruit. Upon the evaluation of anti-inflammatory effects, the flavonoid 1 decreased the nitric oxide production in macrophage cells with high efficiency, viz, $50 \%$ inhibition concentration, $I C_{50}$ of $57.4 \mu M$. Subsequent studies demonstrated that PMF 1 effectively inhibited the generation of PGE2, TNF- $\alpha$, IL-1 $\beta$, and IL-6 cytokine in a dose-dependent manner.

Conclusion: Tetramethyl-O-scutellarin (1) has been successfully isolated from Shiranuhi species for the first time. Thus, Shiranuhi fruit peel extract containing PMF 1 can potentially be applied as an antiinflammatory ingredient in food or cosmetic industries.
\end{abstract}

Keywords: Shiranuhi fruit, Nitric oxide, Tetramethyl-O-scutellarin, Anti-inflammatory

\begin{abstract}
Tropical Journal of Pharmaceutical Research is indexed by Science Citation Index (SciSearch), Scopus, International Pharmaceutical Abstract, Chemical Abstracts, Embase, Index Copernicus, EBSCO, African Index Medicus, JournalSeek, Journal Citation Reports/Science Edition, Directory of Open Access Journals (DOAJ), African Journal Online, Bioline International, Open-J-Gate and Pharmacy Abstracts
\end{abstract}

\section{INTRODUCTION}

Citrus is a genus of trees producing important fruits such as oranges, lemons, grapefruit, and limes. Mandarine oranges (C. reticulata) are widely cultivated in subtropical areas of China, Japan, and Korea. The dried peels of Citrus fruits have been used in Chinese medicine for the cure of stomachache, skin inflammation, muscle pain, cough, and high blood pressure [1]. Phytochemical studies of Citrus peels have led to identifying some metabolites including flavonoids [2,3], limonoids [4,5], and coumarins [6]. Polymethoxyflavones (PMFs) have attracted considerable attention as bioactive constituents in Citrus peels $[2,7]$ owing to their antiinflammatory [8], anticarcinogenic [9], and antiatherogenic properties [10]. Besides, 
antioxidant [11,12] and antitumor properties [13] were also identified from the flavonoids of Citrus genus.

Shiranuhi is the generic name of a hybrid Citrus species [(Citrus unshiu Marc. $\times$ C. sinensis Osbeck) $\times$ C. Reticulata Blanco)], and its fruit is large size with a characteristic sweet taste. Shiranuhi fruit (Korean name, Hallabong) is produced in large quantities from orchards in Jeju Island, Korea [14]. Within the Citrus species, Shiranuhi is relatively unexplored as the source of phytochemical studies searching for cosmeceutical or functional food ingredients. In the process of our investigation to develop bioactive ingredients from the plants available in Jeju Island, the ethanol extracts prepared from the peels of immature Shiranuhi fruit exhibited anti-inflammatory activities. Therefore, we decided to identify the chemical constituents responsible for the activities.

Polymethoxyflavonoid compounds have been isolated from various Citrus plants including $C$. sinensis and $C$. reticulata $[15,16]$. Essential oil from the peels of Shiranuhi exhibited high radical scavenging and anti-bacterial activities [17]. So far, there is no report on the ingredients responsible for the anti-inflammatory activity from Shiranuhi plant. The anti-inflammatory activities of the extracts and the isolated compound were determined by LPS-induced RAW264.7 murine macrophage cells.

\section{EXPERIMENTAL}

\section{Plant material}

Immature Shiranuhi peels were collected from the Citrus Research Institute (RDA) in Jeju Island, South Korea. An authenticated voucher specimen (no. 463) was deposited at the herbarium of Natural Product Chemistry, Department of Chemistry and Cosmetics, Jeju National University.

\section{Extraction and isolation}

Immature Shiranuhi peels $(1,085 \mathrm{~g})$ were dried in the shade and extracted with $80 \%$ ethanol three times by stirring using a mechanical stirrer at room temperature for $24 \mathrm{~h}$. The combined ethanol extract was filtered, and the filtrate was concentrated using a vacuum evaporator to give a gummy extract $(146.8 \mathrm{~g})$. A part of the citrus extract $(60.0 \mathrm{~g})$ was suspended in distilled water $(3 \mathrm{~L})$ and fractionated with three solvents $(n-$ hexane, ethyl acetate, and $n$-butanol), affording the corresponding solvent fractions and water residue. Among the fractions, the EtOAc-soluble fraction $(5.0 \mathrm{~g})$ was purified by medium-pressure liquid chromatography (MPLC, Biotage co.) instrument equipped with a $\mathrm{C}_{18} \mathrm{SiO}_{2}$ column (KP$\mathrm{C}_{18} \mathrm{HS}$, Biotage Co.). Elution of the fraction with $\mathrm{H}_{2} \mathrm{O}-\mathrm{MeOH}(10-100 \%)$ solvent gradient provided 39 subfractions. Among them, subfraction 31 (126.8 $\mathrm{mg}$ ) was identified as the pure compound. Analytical grade solvents were used in this experiment. ${ }^{1} \mathrm{H}$ and ${ }^{13} \mathrm{C}$ nuclear magnetic resonance spectra ( ${ }^{1} \mathrm{H}$ NMR, $500 \mathrm{MHz}$; ${ }^{13} \mathrm{C}$ NMR, $125 \mathrm{MHz}$ ) were obtained using an AVANCE III (FT-NMR system, Bruker co.) instrument, and the chemical shift $(\delta)$ data are reported in ppm relative to the NMR solvent used. Electrospray ionization (ESI) mass analyses were performed on a Waters Quattro micro Tandem mass system (Waters, USA).

\section{Cell culture}

Murine macrophage RAW264.7 cell line was purchased from American Type Cell Culture (Rockville, MD, USA). The cell (RAW264.7) culture was prepared in Dulbecco's modified Eagle's medium (GIBCO Inc., NY, USA) supplemented with streptomycin $(100 \mu \mathrm{g} / \mathrm{mL})$, penicillin $(100 \mathrm{U} / \mathrm{mL})$, and $10 \%$ fetal bovine serum (GIBCO Inc., NY, USA). The cells were incubated in $5 \% \mathrm{CO}_{2}$ atmosphere at $37^{\circ} \mathrm{C}$.

\section{WST-1 assay for cell viability}

Tetrazolium salt WST-1 [2-(4-iodophenyl)-3-(4nitrophenyl)-5-(2,4-disulfophenyl)-2H-tetrazolium] (Roche, Germany) was employed for the cell viability assays. The assay was performed following the manufacturer protocol. Murine RAW264.7 macrophage cells $\left(1.5 \times 10^{5}\right.$ cells $\left./ \mathrm{mL}\right)$ were cultured in 24-well plate for $18 \mathrm{~h}$, followed by treatment with $1 \mu \mathrm{g} / \mathrm{mL}$ of LPS in the presence of various samples. After $24 \mathrm{~h}$ cell incubation, WST-1 was added to the medium and it was allowed to stand for $1 \mathrm{~h}$. The supernatant was measured at $440 \mathrm{~nm}$ with reference $600 \mathrm{~nm}$. Cell viability was determined as the ratio of the sample absorbance to that of control.

\section{Measurement of nitric oxide concentration}

The NO production was determined by the Griess reagent (Sigma, USA). In this assay, the accumulated nitrite ion originated from the NO in the culture medium was monitored by a colorimetric method. Briefly, after RAW264.7 macrophage cells $\left(1.5 \times 10^{5}\right.$ cells $\left./ \mathrm{mL}\right)$ were incubated for $18 \mathrm{~h}$, the cells were treated with LPS and various concentrations of samples (total volume, $1 \mu \mathrm{g} / \mathrm{mL}$ ) for $24 \mathrm{~h}$. Then, the equal volume of Griess reagent was added to the 
supernatant, and incubated at room temperature for $10 \mathrm{~min}$. The produced nitrite ion was determined using a microplate reader (Sunrise ${ }^{\mathrm{TM}}$, Tecan Group Ltd., Switzerland) at a wavelength of $540 \mathrm{~nm}$. The percent inhibition for each sample was calculated as.

Inhibition $(\%)=[($ Control - Sample $) /$ Control $] \times$ 100

Measurement of prostaglandin $E_{2}\left(P G E_{2}\right)$ and cytokines

The production of $\mathrm{PGE}_{2}$ and pro-inflammatory cytokines (TNF- $\alpha$, IL-1 $\beta$, and IL-6) was determined in the culture supernatant of RAW264.7 cells. In a 24-well cell culture plate, the macrophage cells were placed at an appropriate density $\left(1.5 \times 10^{5}\right.$ cells $\left./ \mathrm{mL}\right)$ with culture medium $(1 \mathrm{~mL})$ and incubated for $18 \mathrm{~h}$. Then, the cells were treated with a sample (specified concentration) and LPS $(1 \mu \mathrm{g} / \mathrm{mL})$ and incubated for an additional $24 \mathrm{~h}$. The amount of $\mathrm{PGE}_{2}, \mathrm{TNF}-\alpha, \mathrm{IL}-1 \beta$, and IL- 6 produced by the cells was measured using an ELISA kit $\left(\mathrm{PGE}_{2}\right.$, IL-1 $\beta$; R\&D systems, TNF- $\alpha$, IL-6; Invitrogen) and a microplate reader according to the manufacturer's instructions.

\section{Statistical analysis}

Means ( \pm standard error of the mean) of the data are presented, and statistical analysis of the results was carried out by Student's t-test using Microsoft Excel 2013 (Microsoft Corporation, USA) for independent samples. Values of $p$ $<0.05$ and $p<0.01$ were considered significant as appropriate.

\section{RESULTS}

At first, the ethanol extracts were examined for the anti-inflammatory activities using RAW 264.7 cells. The extract $(100 \mu \mathrm{g} / \mathrm{mL})$ prepared from the immature Shiranuhi peels inhibited LPS-induced NO production in the macrophage cells by $8 \%$ (Figure 1). The ultimate goal of this study was to determine the anti-inflammatory chemical constituents in the extracts. Thus, the extract was partitioned in the order of polarity using

(A)

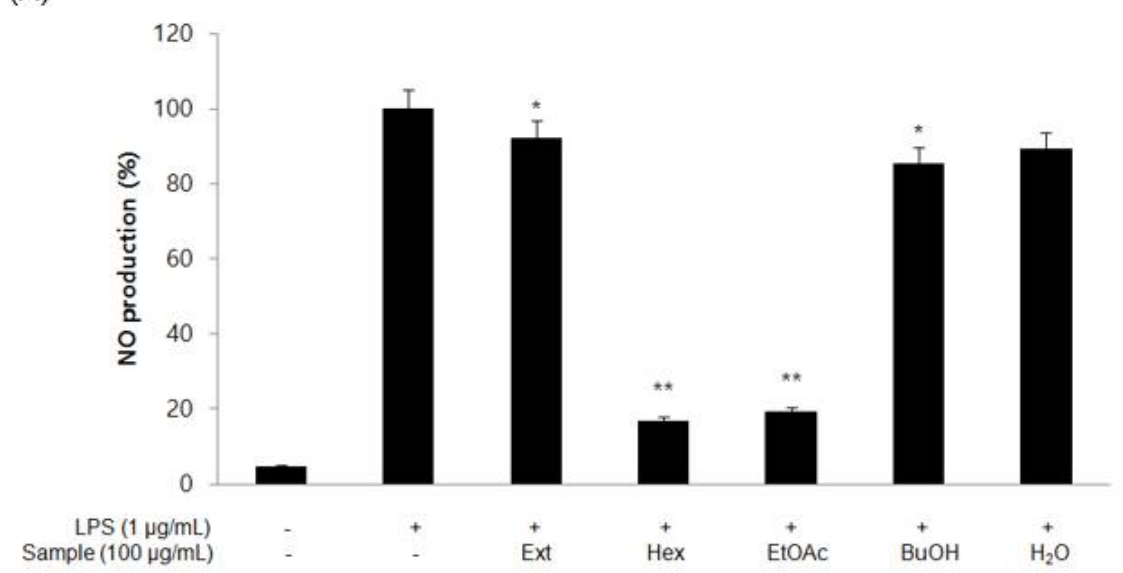

(B)

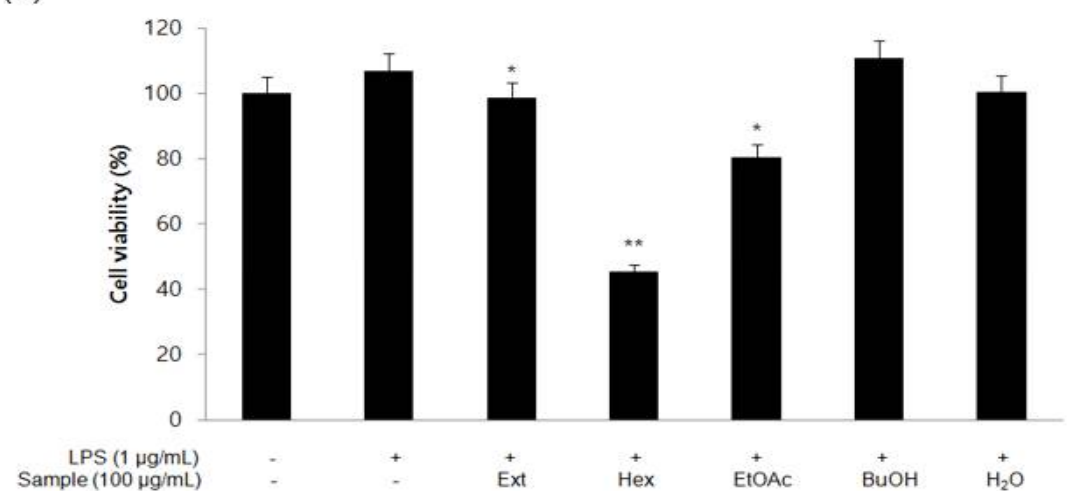

Figure 1: Effect of extract and solvent fractions from immature Shiranuhi peel on NO production (A) and cell viability (B) in LPS-induced RAW264.7 cells. The cells were stimulated with $1 \mu \mathrm{g} / \mathrm{mL}$ of LPS only, or with LPS plus sample $(100 \mu \mathrm{g} / \mathrm{mL})$ for $24 \mathrm{~h}$. Values are the mean \pm SEM of triplicate experiments; ${ }^{*} p<0.05 ;{ }^{* *} p<0.01$ versus LPS alone 
(A)

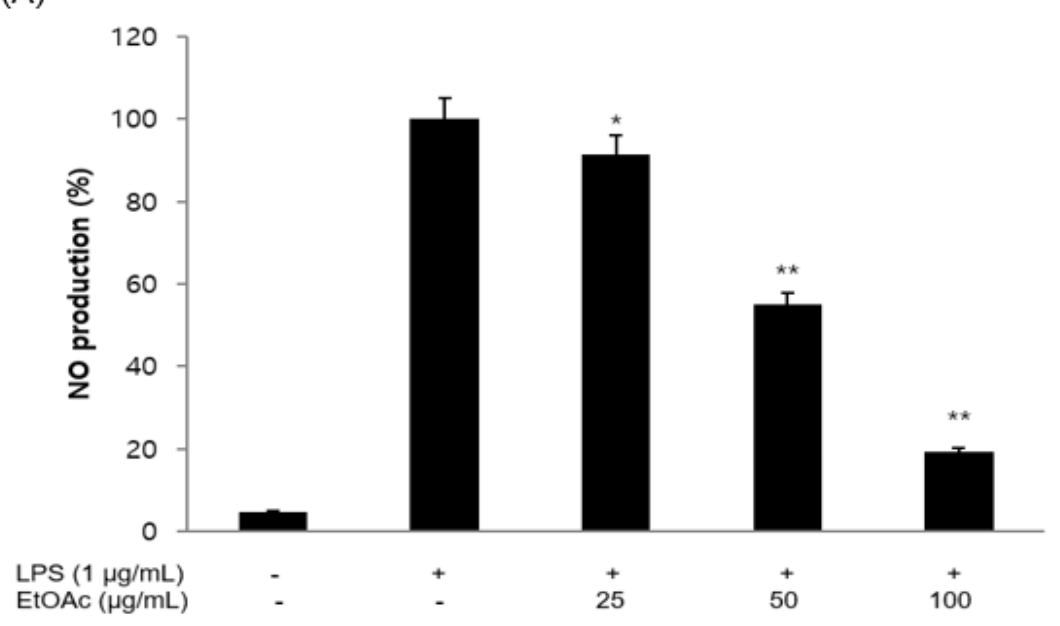

(B)

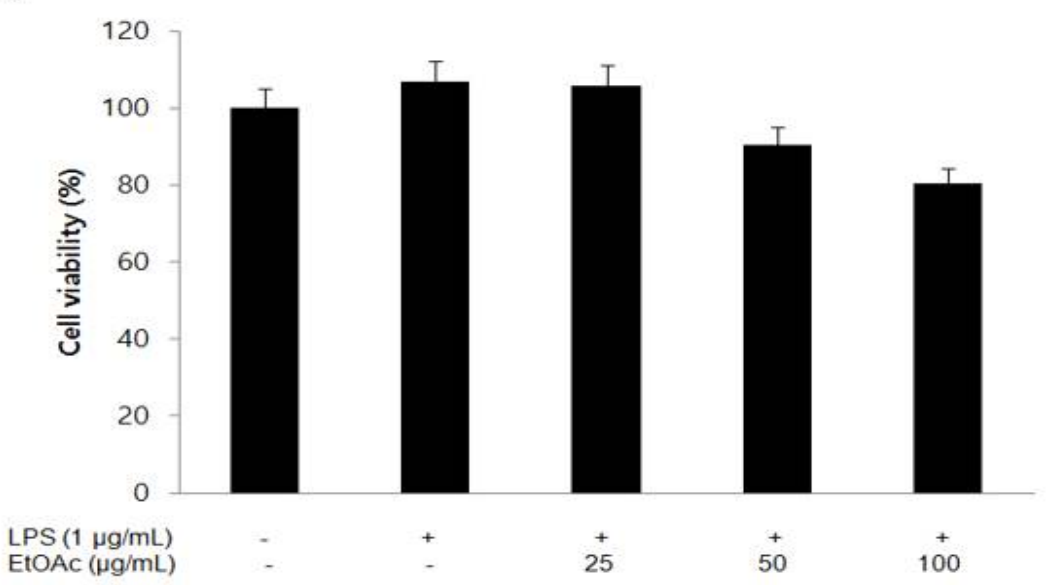

Figure 2: Effect of ethyl acetate (EtOAc) fractions on NO production (A) and cell viability (B) in LPS-induced RAW264.7 cells. The cells were stimulated with $1 \mu \mathrm{g} / \mathrm{mL}$ of LPS only, or with LPS plus various concentrations $(25,50$, and $100 \mu \mathrm{g} / \mathrm{mL})$ of samples for $24 \mathrm{~h}$. Values are the mean \pm SEM of triplicate experiments; ${ }^{*} p<0.05$; ${ }^{* *} p$ $<0.01$ versus $L P S$ alone

solvents ( $n$-hexane, EtOAc, and $n$-butanol) to afford corresponding fractions as well as the remaining water residue. Each solvent fraction was again subjected to the activity test for the generation of NO. Figure $1 \mathrm{~A}$ shows that both the $n$-hexane and EtOAc fractions possess strong NO inhibition activities. However, the WST-1 assay indicated that the $n$-hexane fraction have considerable cell toxicity. In contrast, the EtOAc fraction mostly maintained cell viability at a concentration up to $100 \mu \mathrm{g} / \mathrm{mL}$, indicating that the cell-destruction effect is rarely involved in the observed NO inhibition. Figure 2 shows the NO inhibition and cell toxicity data of the EtOAc fraction under various concentrations $(25-100$ $\mu \mathrm{g} / \mathrm{mL}$ ), indicating that the EtOAc fraction decreased the NO generation in a dosedependent manner. The EtOAc fraction was selected for further purification to isolate the active ingredient, because it strongly inhibited
NO synthesis without causing cell toxicity at 100 $\mu \mathrm{g} / \mathrm{mL}$ (Figure 2B).

EtOAc fraction was separated by MPLC and silica gel column chromatography, leading to the isolation of compound 1 . The chemical structure of compound 1 was elucidated by the interpretation of the ${ }^{1} \mathrm{H}$ and ${ }^{13} \mathrm{C}$ NMR spectra. Compound 1 showed 13 carbon peaks in the ${ }^{13} \mathrm{C}$ NMR spectrum, a characteristic indication of the presence of a flavone skeleton. The signal at $\delta$ $177.4 \mathrm{ppm}$ in the ${ }^{13} \mathrm{C}$ NMR spectrum indicates the presence of a carbonyl group at C-4 position. The ${ }^{13} \mathrm{C}$ signals at $\delta 62.4,61.7,56.4$, and 55.6 ppm correspond to the four methoxy groups at the C-5, C- $6, \quad \mathrm{C}-7$, and C-4' positions, respectively.

The ${ }^{1} \mathrm{H}$ NMR spectrum of compound 1 revealed that it has an $\mathrm{A}_{2} \mathrm{~B}_{2}$ system $\left(\mathrm{H}-2^{\prime} / \mathrm{H}-6^{\prime}\right.$ and $\mathrm{H}-3^{\prime} / \mathrm{H}-$ $\left.5^{\prime}\right)$, as demonstrated by the coupling constant 
signals at $\delta 7.81\left(\mathrm{~d}, \mathrm{H}-2^{\prime}, \mathrm{H}-6^{\prime}\right)$ and $\delta 6.99(\mathrm{~d}, \mathrm{H}-$ $3^{\prime}, \mathrm{H}-5^{\prime}$ ), and one methoxy group at position $\mathrm{C}-4^{\prime}$. The aromatic proton singlet signals at $\delta 6.56$ and $6.77 \mathrm{ppm}$ were assigned to the $\mathrm{H}-3$ and $\mathrm{H}-8$ in the structure. Four proton signals for the methoxy groups at the $\mathrm{H}-5, \mathrm{H}-6, \mathrm{H}-7$ and $\mathrm{H}-4^{\prime}$ were observed at $\delta_{H} 3.86,3.89,3.95$, and 3.96 , respectively.<smiles>COc1ccc(-c2cc(=O)c3c(OC)c(OC)c(OC)cc3o2)cc1</smiles>

Figure 3: Structure of tetramethyl-O-scutellarin (1) isolated from immature Shiranuhi peel

By careful examination of the NMR data discussed above, compound $\mathbf{1}$ was identified as a polymethoxyflavone, tetramethyl-O-scutellarin (Figure 3). The ${ }^{1} \mathrm{H}$ NMR and ${ }^{13} \mathrm{C}$ NMR data are as follows: ${ }^{1} \mathrm{H}$ NMR $\left(500 \mathrm{MHz}, \mathrm{CDCl}_{3}\right) \delta 7.81$ $\left(2 \mathrm{H}, \mathrm{d}, J=9.0, \mathrm{H}-2^{\prime}, 6^{\prime}\right), 6.99(2 \mathrm{H}, \mathrm{d}, J=9.0, \mathrm{H}-$ $\left.3^{\prime}, 5^{\prime}\right), 6.77(1 \mathrm{H}, \mathrm{s}, \mathrm{H}-8), 6.56(1 \mathrm{H}, \mathrm{s}, \mathrm{H}-3), 3.96$ $\left(3 \mathrm{H}, \mathrm{s}, 4{ }^{\prime}-\mathrm{OCH}_{3}\right), 3.95\left(3 \mathrm{H}, \mathrm{s}, 7^{\prime}-\mathrm{OCH}_{3}\right), 3.89$ $\left(3 \mathrm{H}, \mathrm{s}, 6-\mathrm{OCH}_{3}\right), 3.86\left(3 \mathrm{H}, \mathrm{s}, 5-\mathrm{OCH}_{3}\right) ;{ }^{13} \mathrm{C} \mathrm{NMR}$ $\left(125 \mathrm{MHz}, \mathrm{CDCl}_{3}\right) \delta 177.4$ (C-4), 162.3 (C-2), 161.3 (C-4'), 157.8 (C-7), 154.6 (C-5), 152.7 (C9), 140.4 (C-6), 127.8 (C-2', 6'), 124.0 (C-1'), 114.5 (C-3', 5'), 113.0 (C-10), 107.2 (C-3), 96.4 $(\mathrm{C}-8), 62.4\left(5-\mathrm{OCH}_{3}\right), 61.7\left(6-\mathrm{OCH}_{3}\right), 56.4$ (7$\left.\mathrm{OCH}_{3}\right), \quad 55.6\left(4^{\prime}-\mathrm{OCH}_{3}\right)$. ESIMS (positive-ion mode): $m / z 343(\mathrm{M}+\mathrm{H})^{+}$. The suggested structure was finally confirmed by the comparison of the observed data to the literature values [18]. As far as we know, tetramethyl-O-scutellarin (1) was isolated for the first time from Shiranuhi fruit.

The bioactivity test flavonoid $\mathbf{1}$ was also tested using RAW 264.7 cells under under varying concentrations $(25,50$, and $100 \mu \mathrm{M})$. When activated by LPS, RAW 264.7 cells increased the nitric oxide (NO) production by 12 fold (Figure 4A). The treatment of tetramethyl-O-scutellarin (1) to the activated macrophage cells decreased
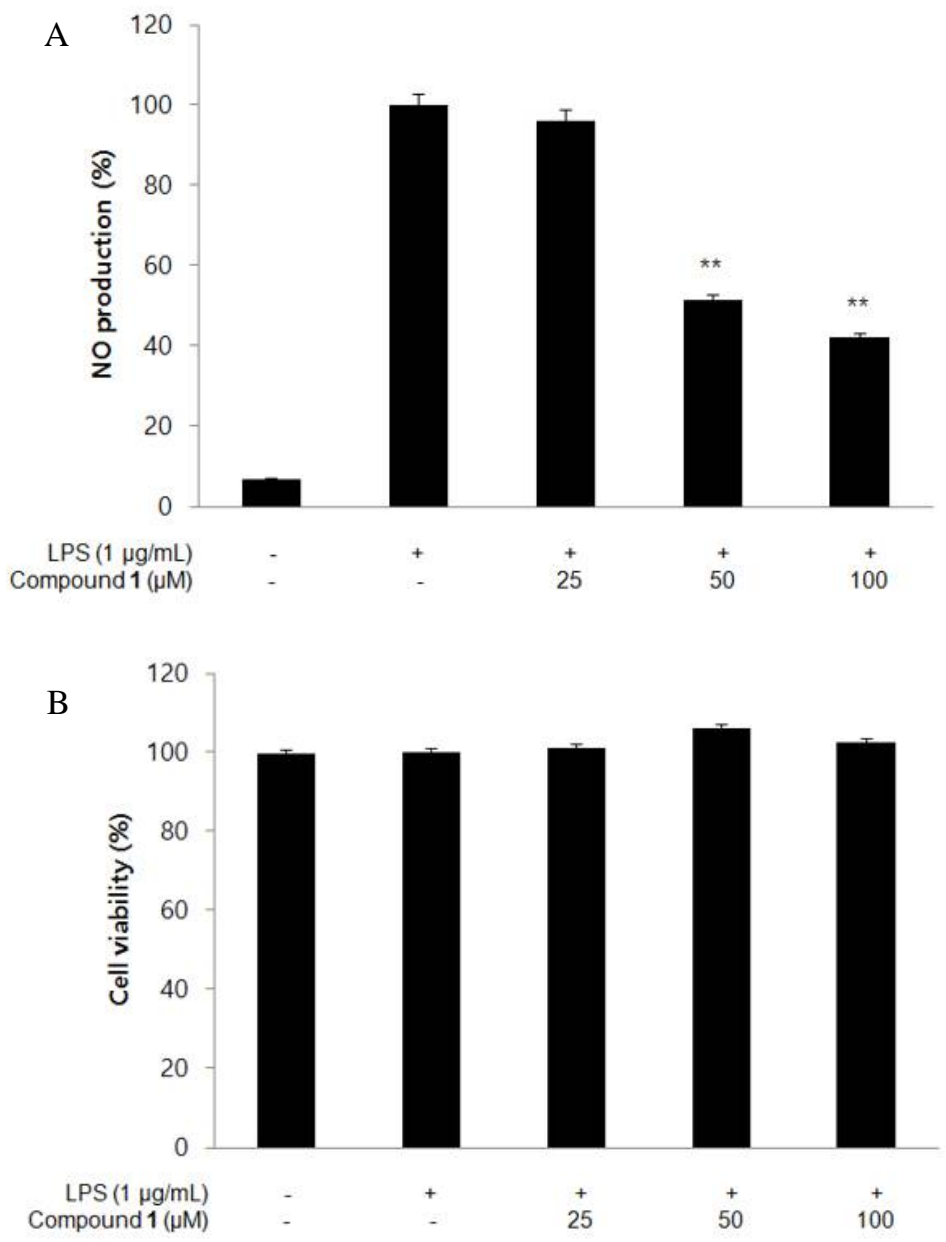

Figure 4: Effect of tetramethyl-O-scutellarin (1) on NO production (A) and cell viability (B) in LPS-induced RAW264.7 macrophage cells. The cells were stimulated with $1 \mu \mathrm{g} / \mathrm{mL}$ of LPS only, or with LPS plus various concentrations $(25,50$, and $100 \mu \mathrm{M})$ of samples for $24 \mathrm{~h}$. Values are the mean \pm SEM of triplicate experiments * $p$ $<0.05 ;{ }^{* *} p<0.01$ versus LPS alone 
the $\mathrm{NO}$ production with high efficiency $\left(\mathrm{IC}_{50}=\right.$ $57.4 \mu \mathrm{M})$ ) in a dose dependent manner. The potential cytotoxicity of the isolate $\mathbf{1}$ was determined by the WST-1 assay, where the cells were incubated for $24 \mathrm{~h}$ with or without LPS (Figure 4B). In this test, cell viability mostly unchanged at the employed concentrations (25, 50 , and $100 \mu \mathrm{M})$, suggesting that the $\mathrm{NO}$ inhibitory effect of isolate $\mathbf{1}$ had nothing to do with its cell toxicity. To further elucidate the antiinflammatory mechanism of PMF 1, inflammation-related substances such as $\mathrm{PGE}_{2}$, IL-6, IL-1 $\beta$, and TNF- $\alpha$ were monitored in culture supernatants by ELISA. As shown in Figure 5, LPS-activated RAW 264.7 cells significantly produced the inflammatory cytokines (Figure 5). This experiment clearly revealed that flavonoid 1 reduced the production of the cytokines $\left(\mathrm{PGE}_{2}\right.$, TNF- $\alpha$, IL-1 $\beta$, and IL-6) with high to medium degree in a concentration dependent manner (Figure 5 and Figure 6).

\section{DISCUSSION}

If body tissue is exposed to a variety of stimuli, inflammation occurs as a biological response. Inflammation is commonly characterized by blood flow increase to the damaged tissue inducing temperature rise, redness, swelling and pain. It is mediated by different types of signaling molecules produced by various cells. Macrophages play an important role in inflammation-related disease through the secretion of molecular mediators such as $\mathrm{NO}$, $\mathrm{PGE}_{2}$ as well as relevant cytokines including tumor necrosis factor (TNF)- $\alpha$, interleukin (IL)-1 $\beta$, and IL-6 [19].

Polymethoxyflavones (PMFs) are a class of compounds, with flavones as a base structure and methoxy substituents in different positions. Interestingly, PMFs exist mainly in Citrus genus in the plant kingdom. More than 30 PMFs have

(A)

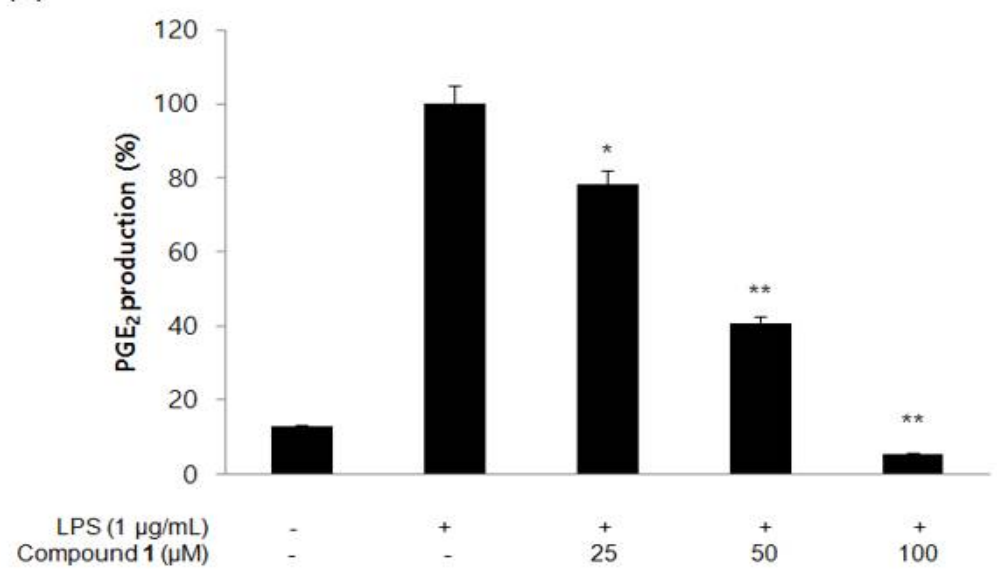

(B)

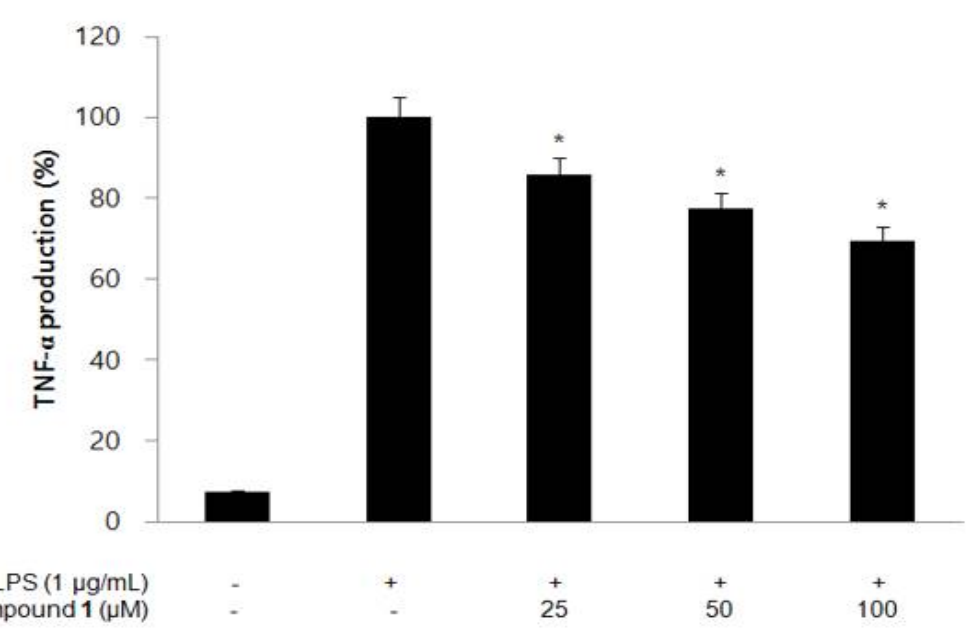

Figure 5: Effect of tetramethyl-O-scutellarin (1) on PGE 2 (A) and TNF- $\alpha$ (B). The cells were stimulated with 1 $\mu \mathrm{g} / \mathrm{mL}$ of LPS only, or with LPS plus various concentrations $(25,50$, and $100 \mu \mathrm{M})$ of samples for $24 \mathrm{~h}$. Values are the mean \pm SEM $(\mathrm{n}=3) ;{ }^{*} p<0.05 ;{ }^{* *} p<0.01$ versus LPS alone 
(A)

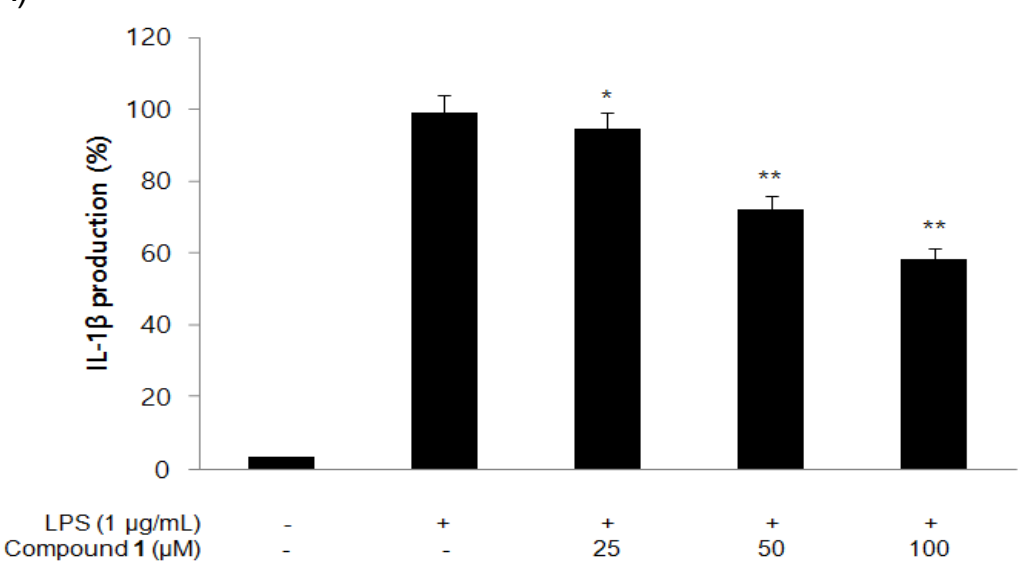

(B)

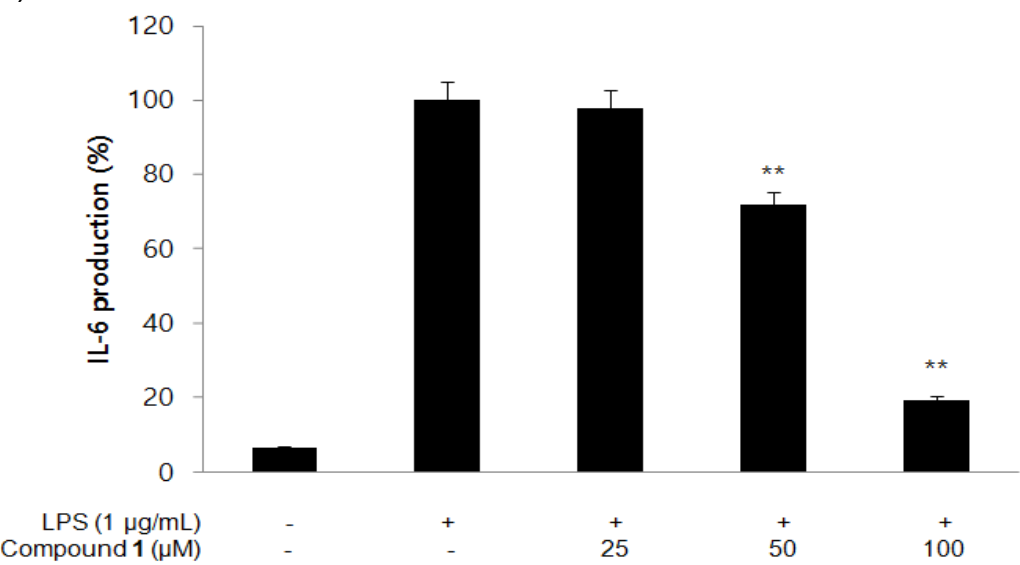

Figure 6: Effect of tetramethyl-O-scutellarin (1) on IL-1 $\beta$ (A) and IL-6 (B) production in LPS-induced RAW264.7 macrophage cells. The cells were stimulated with $1 \mu \mathrm{g} / \mathrm{mL}$ of LPS only, or with LPS plus various concentrations $(25,50$, and $100 \mu \mathrm{M})$ of samples for $24 \mathrm{~h}$. Values are the mean \pm SEM $(n=3) ;{ }^{*} p<0.05 ;{ }^{* *} p<0.01$ versus LPS alone

been isolated from different parts of the citrus species including mandarin (C. reticulata Blanco)and sweet orange (C. sinensis) [20]. The structural types and ingredient contents of PMFs vary between different varieties of citrus plants. Among those isolated PMF derivatives, nobiletin and tangeretin have been intensively explored owing to their availability and interesting pharmacological activities. Numerous studies suggest that PMF compounds isolated from citrus display a broad spectrum of biological activity [21].

In this study, we isolated a polymethoxyflavonoid, tetramethyl-O-scutellarin (1) as an active constituent from immature Shiranuhi peel and examined its anti-inflammatory activities. Shiranuhi is a hybrid Citrus species, and its fruit is produced in large quantities in Jeju Island of Korea. The isolated PMF 1 strongly inhibited the NO production with a high efficiency $\left(\mathrm{IC}_{50} 57.4\right.$ $\mu \mathrm{M})$. The subsequent studies demonstrated that the flavonoid 1 effectively reduced the secretion of prostaglandin $\mathrm{E}_{2}$ as well as the production of pro-inflammatory cytokines such as tumor necrosis factor-alpha, interleukin (IL)-1 $\beta$, and IL6 in a dose dependent manner.

\section{CONCLUSION}

Tetramethyl-O-scutellarin (1) has successfully been isolated for the first time from Shiranuhi citrus species. PMF compound 1 possesses antiinflammatory properties as indicated by the suppression of NO, PGE 2 , IL-6, IL-1 $1 \beta$, and TNF- $\alpha$ production in LPS-triggered macrophage RAW 264.7 cells. The control of pro-inflammatory mediators (NO, TNF- $\alpha$, and IL-6) has been an effective strategy for the development of novel anti-inflammatory materials. Thus, the results suggest that tetramethyl-O-scutellarin (1) derived from a citrus might be a potential agent for the treatment of inflammation-associated human health problems. 


\section{DECLARATIONS}

\section{Acknowledgement}

This work was carried out with the support of Cooperative Research Program for Agriculture Science \& Technology Development (Project no. PJ010934072016), Rural Development Administration, Republic of Korea.

\section{Conflict of Interest}

No conflict of interest associated with this work.

\section{Contribution of Authors}

The authors declare that this work was done by the authors named in this article and all liabilities pertaining to claims relating to the content of this article will be borne by them.

\section{Open Access}

This is an Open Access article that uses a funding model which does not charge readers or their institutions for access and distributed under the terms of the Creative Commons Attribution License (http://creativecommons.org/licenses/by/ 4.0) and the Budapest Open Access Initiative (http://www.budapestopenaccessinitiative.org/rea d), which permit unrestricted use, distribution, and reproduction in any medium, provided the original work is properly credited.

\section{REFERENCES}

1. Li S, Pan MH, Lo CY, Tan D, Wang Y, Shahidi F, Ho CT. Chemistry and health effects of polymethoxyflavones and hydroxylated polymethoxyflavones. J Funct Foods 2009; 1: 2-12.

2. Tatum JH, Berry RE. Six new flavonoids from Cirus. Phytochem 1972; 11: 2283-2288.

3. Horie T, Tsukayama M, Yamada T, Miura I, Nakayama M. Three flavone glycosides from Citrus sudachi. Phytochem 1986; 25: 2621-2624.

4. Hasegawa $S$, Raymond $D B$, Zareb H. A limonoid from young calamondin seedlings. Phytochem 1986; 25 : 1984-1985.

5. Raymond DB, Miyake M, Ozaki $Y$, Hasegawa S. Limonoid glucosides in Citrus aurantium. Phytochem 1991; 30: 3803-3805

6. Tatum JH, Berry RE. Coumarins and psoralens in grapefruit peel oil. Phytochem 1979; 18: 500-502.

7. Maris AA, Panagiotis $K$, Eugenios $K$, Andreana NA, Vassilios PP. Analysis of antioxidant compounds in sweet orange peel by HPLC-diode array detectionelectrospray ionization mass spectrometry. Biomed Chromatog 2005; 19: 138-148.
8. Murakami A, Shigemori T, Ohigashi H. Zingiberaceous and citrus constituents, 10-acetoxychavicol acetate, zerumbone, auraptene, and nobiletin, suppress lipopolysaccharide-induced cyclooxygenase-2 expression in RAW 264.7 murine macrophages through different modes of action. J Nutr 2005; 135: 2987-2992.

9. Lai CS, Li S, Chai CY, Lo CY, Ho CT, Wang YJ, Pan MH. Inhibitory effect of citrus 5-hydroxy-3,6,7,8,30,40hexamethoxyflavone on 12-O-tetradecanoylphorbol 13acetate-induced skin inflammation and tumor promotion in mice. Carcinogenesis 2007; 28: 2581-2588.

10. Kurowska EM, Manthey JA. Hypolipidemic effects and absorption of citrus polymethoxylated flavones in hamsters with diet-induced hypercholesterolemia. J Agric Food Chem 2004; 52: 2879-2886.

11. Jeong WS, Park SW, Chung SK. The antioxidative activity of Korean Citrus unshiu peels. Food Biotechnol 1997; 6: 292-296.

12. Su MS, Shyu YT, Chien PJ. Antioxidant activities of citrus herbal product extracts. Food Chem 2008; 111: 892896.

13. Yoshiki M, Takashi S, Keisuke I, Akira D, Masamichi Y, Akira I. A citrus polymethoxyflavonoid, nobiletin, is a novel MEK inhibitor that exhibits antitumor metastasis in human fibrosarcoma HT-1080 cells. Biochem Biophys Res Commun 2008; 366: 168-173.

14. Oh SI. Citrus. Korea Rural Economic Institute, 2010; 317: 6-8.

15. Ortuñ o A, Bá idez A, Gó mez P, Arcas MC, Porras I, García A, Río JA. Citrus paradisi and Citrus sinensis flavonoids: Their influence in the defence mechanism against Penicillium digitatum. Food Chem 2006; 98: 351-358.

16. Qizhen D, Hui C. The methoxyflavones in Citrus reticulata Blanco $\mathrm{cv}$. ponkan and their antiproliferative activity against cancer cells. Food Chem 2013; 119: 567-572.

17. Kim SS, Hyun JM, Kim KS, Park KJ, Park SM, Choi YH. Influence of Essential Oil in 'Shiranuhi' Immature Fruit on Antioxidant and Antimicrobial Activities. Korea J Medicinal Crop Sci 2013; 261: 493-497.

18. Miyazawa M, Okuno Y, Fukuyama M, Nakamura $S$, Kosaka H. Anti-mutagenic Activity of Polymethoxyflavonoids from Citrus aurantium. J Agric Food Chem 1999; 47: 5239-5244.

19. Guastadisegni C, Nicolini A, Balduzzi M, Ajmone-Cat MA, Minghetti L. Modulation of PGE2 and TNF- $\alpha$ by nitric oxide in resting and LPS-activated RAW 264.7 cells. Cytokine 2002; 19: 175-180.

20. Jayaprakasha GK, Negi PS, Sikder S, Rao LJ, Sakariah KK. Antibacterial activity of Citrus reticulata peel extracts. Z Naturforsch C 2000; 55: 1030-1034.

21. Chen J, Montanari AM. Isolation and identification of new polymethoxyflavonoids from dancy tangerine leaves. J Agric Food Chem 1998; 46: 1235-1238.

22. Li S, Pan MH, Lai CS, Lo CY, Dushenkov S, Ho CT. Isolation and syntheses of polymethoxyflavones and 
Hyun et al

hydroxylated polymethoxyflavones as inhibitors of HL-60

cell lines. Bioorg Med Chem 2007; 15: 3381-338

Trop J Pharm Res, September 2017; 16(9): 2205 